\title{
Dysregulation of Angiotensin Converting Enzyme 2 Expression and Function in Comorbid Disease Conditions Possibly Contributes to Coronavirus Infectious Disease 2019 Complication Severity
}

\author{
Safaa H Hammoud,1 Zena Wehbe, ${ }^{1}$ Samar Abdelhady, Firas Kobeissy, Ali H. Eid, \\ and Ahmed F. El-Yazbi
}

Department of Pharmacology and Therapeutics, Beirut Arab University, Beirut, Lebanon (S.H.); Departments of Biology (Z.W.), Biochemistry and Molecular Genetics (F.K.), and Pharmacology and Toxicology (A.H.E., A.F.E.-Y.), American University of Beirut, Beirut, Lebanon; Department of Pharmacology and Toxicology, Faculty of Pharmacy (A.F.E.-Y.) and Faculty of Medicine (S.A.), Alexandria University, Alexandria, Egypt; and Department of Basic Medical Sciences, College of Medicine, and Biomedical and Pharmaceutical Research Unit, QU Health, Qatar University, Doha, Qatar (A.H.E.)

Received July 16, 2020; accepted October 9, 2020

\section{ABSTRACT}

ACE2 has emerged as a double agent in the COVID-19 ordeal, as it is both physiologically protective and virally conducive. The identification of ACE2 in as many as 72 tissues suggests that extrapulmonary invasion and damage is likely, which indeed has already been demonstrated by cardiovascular and gastrointestinal symptoms. On the other hand, identifying ACE2 dysregulation in patients with comorbidities may offer insight as to why COVID-19 symptoms are often more severe in these individuals. This may be attributed to a pre-existing proinflammatory state that is further propelled with the cytokine storm induced by SARS-CoV-2 infection or the loss of functional ACE2 expression as a result of viral internalization. Here, we aim to characterize the distribution and role of ACE2 in various organs to highlight the scope of damage that may arise upon SARSCoV-2 invasion. Furthermore, by examining the disruption of ACE2 in several comorbid diseases, we offer insight into potential causes of increased severity of COVID-19 symptoms in certain individuals.

\section{SIGNIFICANCE STATEMENT}

Cell surface expression of ACE2 determines the tissue susceptibility for coronavirus infectious disease 2019 infection. Comorbid disease conditions altering ACE2 expression could increase the patient's vulnerability for the disease and its complications, either directly, through modulation of viral infection, or indirectly, through alteration of inflammatory status.

\section{Introduction}

The Renin-Angiotensin System. The renin-angiotensin system (RAS) plays a key role in regulating the normal physiology and pathogenesis of cardiovascular diseases (CVDs). RAS mainly consists of a series of enzymatic reactions, with

This work was supported by the Medical Practice Plan Grants from the Faculty of Medicine at the American University of Beirut [320148] to A.F.E.-Y. and the Medical Practice Plan Grants from the Faculty of Medicine at the American University of Beirut [320133] to A.H.E.

${ }^{1}$ S.H. and Z.W. contributed equally to this work.

https://doi.org/10.1124/molpharm.120.000119. renin being the rate-limiting enzyme and angiotensin (Ang) II, generated by local RAS, being the major component acting on angiotensin receptor $1\left(\mathrm{AT}_{1} \mathrm{R}\right)$ and angiotensin receptor 2 $\left(\mathrm{AT}_{2} \mathrm{R}\right)$. Overstimulation of the "classic" RAS pathway involving the activation of angiotensin converting enzyme (ACE) 1 (AngII/AT $\left.{ }_{1} \mathrm{R}\right)$ results in vasoconstriction, inflammation, sodium and water retention, and oxidative stress generation, thus increasing sympathetic nervous system activity, cardiovascular fibrosis, and hypertrophy. The view of RAS has changed with the identification of an ACE homolog, ACE2 (Donoghue et al., 2000). A more complex signaling network

ABBREVIATIONS: ACE, angiotensin converting enzyme; Ang, angiotensin; ARDS, acute respiratory distress syndrome; $\mathrm{AT}_{1} \mathrm{R}$, angiotensin receptor 1; $A T_{2} R$, angiotensin receptor 2; COVID-19, coronavirus infectious disease 2019; CVD, cardiovascular disease; ERK, extracellular signal-regulated kinase; IL, interleukin; JNK, C-Jun N-terminal kinase; MAPK, mitogen-activated protein kinase; MCP-1, monocyte chemoattractant-1; RAS, renin-angiotensin system; S protein, spike protein; SARS, severe acute respiratory syndrome; SARS-CoV, severe acute respiratory syndrome coronavirus; TGF- $\beta$, transforming growth factor- $\beta$; Th, T-helper; TMPRSS2, transmembrane protease serine 2 ; TNF- $\alpha$, tumor necrosis factor- $\alpha$; VEGF, vascular endothelial growth factor. 
mediating protective physiologic effects, along with the detrimental ones, has now been recognized. ACE2 degrades both AngI and AngII into Ang1-9 and Ang1-7, respectively. As such, another arm of RAS, ACE2/Ang1-7 and ACE2/Ang1-9, emerged and is reported to act as a physiologic antagonist to counteract RAS overactivation, although its full physiologic role is still not completely understood (Santos and Ferreira, 2007; van Twist et al., 2014).

Impact of RAS Imbalance on Various Organs. Of relevance to SARS-CoV-2 infection, lungs are rich in RAS components, including ACE1/ACE2. Imbalance in RAS pathways in favor of ACE1 exacerbates pulmonary tissue damage, leading to acute respiratory distress syndrome (ARDS) (Marshall, 2003). AngII promotes pulmonary vasoconstriction, inflammation, and fibrosis (Uhal et al., 2012). Studies have also linked both $\mathrm{AT}_{1} / \mathrm{AT}_{2} \mathrm{R}$ with AngII-induced lung fibrosis via a mitogen-activated protein kinase (MAPK) pathway (Marshall et al., 2000). Further, AngII stimulates transforming growth factor- $\beta$ (TGF- $\beta$ ) and collagen expression in fibroblasts and mediates alveolar epithelial apoptosis in mice via c-Jun N-terminal kinase (JNK) phosphorylation (Uhal et al., 2007, 2011).

On the other hand, the kidney is the main source of renin, the enzyme initiating RAS cascade. Renal $\mathrm{AT}_{1} \mathrm{R}$ expression is important in regulating baseline blood pressure, and the local renal RAS activation underlies hypertension-induced renal damage (Crowley et al., 2006). AngII induces a local immunoinflammatory response, leading to glomerulosclerosis, interstitial fibrosis, albuminuria, and renal failure (Park et al., 2007). A direct link between stimulation of RAS/AT $1 \mathrm{R}$, NADPH oxidase, reactive oxygen species, and renal remodeling was reported (Nistala et al., 2008). Also, AngII initiates fibrosis and inflammation in kidney through stimulation of TGF- $\beta 1$ signaling (Chen et al., 2012) and triggering extracellular signal-regulated kinase (Erk)/p38MAPK/Smad3 (Mothers against decapentaplegic homolog 3) and Rho kinase pathways (Rupérez et al., 2005; Rüster and Wolf, 2011).

Furthermore, RAS exerts additional cardiovascular control through its activity in the brain. Brain-RAS is a central modulator of blood pressure and sympathetic nervous system (Zucker et al., 2014). The AngII/AT ${ }_{1} \mathrm{R}$ pathway activates the brain-derived neurotrophic factor/transmembrane protease serine 2 signaling, inducing p38MAPK-dependent reduction of voltage-gated potassium current and sympathetic excitation (Becker et al., 2015, 2017). Additional pathways involved in the AngII-induced increase in blood pressure and sympathetic activity include Rho kinase activation and reduction of peroxisome proliferator-activated receptor- $\gamma$ DNA binding, as well as downregulation of ACE2 (Xia et al., 2013; Yu et al., 2015; Pellegrino et al., 2016). Higher RAS-driven sympathetic activity increases metabolic rate by activation of brown adipose tissue and brown adipose tissue thermogenesis (Young et al., 2015).

On the immune system, RAS stimulation is found to induce inflammation. Briefly, AngII/AT ${ }_{1} \mathrm{R}$ stimulation induces macrophage infiltration, increased nuclear factor $\kappa$-light-chain enhancer of activated $B$ cells signaling, reactive oxygen species production, and inflammatory cytokine generation (Guo et al., 2011). Further, AngII via $\mathrm{AT}_{1} \mathrm{R}$ and $\mathrm{AT}_{2} \mathrm{R}$ activates $\mathrm{T}$ cells, which in turn increase superoxide and tumor necrosis factor- $\alpha$ (TNF- $\alpha$ ) production (Hoch et al., 2009). Different T-helper (Th) cells contribute to the detrimental cardiovascular effect of AngII by releasing multiple cytokines. Th1 and Th17 secrete interferon- $\gamma$ and IL-17, respectively, participating in AngII-induced hypertension. On the other hand, Th2produced IL-4 has a role in cardiac fibrosis (Madhur et al., 2010; Kamat et al., 2015; Peng et al., 2015). Moreover, AngIIstimulated secretion of the proinflammatory IL-22 from Th22 is involved in AngII-induced hypertension and endothelial dysfunction (Ye et al., 2017).

As such, dysregulation of the RAS system is heavily involved in the pathogenesis of CVDs, including hypertension and heart failure (Simões e Silva et al., 2013; Sparks et al., 2014). In fact, most of the deleterious symptoms of CVDs, like excessive vasoconstriction, inflammation, fibrosis, hypertrophy, and fluid retention, are primarily mediated by the ACE1/ AngII/AT ${ }_{1} \mathrm{R}$ axis (Patel et al., 2016b). RAS components like $\mathrm{ACE} 1$ and $\mathrm{AT}_{1} \mathrm{R}$ exist throughout the heart and vasculature, and their upregulation is involved in pathologic phenotypes of cardiovascular diseases (Patel et al., 2016b; Gonzalez et al., 2019). This was demonstrated by the in vitro treatment of cardiomyocytes with AngII, triggering myocyte hypertrophy, cardiac fibroblast proliferation, and collagen synthesis. Conversely, inhibition of ACE2 in cardiomyocytes in vivo reverses the hypertrophy and fibrosis related to remodeling and heart failure (Patel et al., 2016b). Moreover, inhibition of this system mitigates the morbidity and death rate among these patients (Zaman et al., 2002).

ACE2 as the Protective Arm of the RAS System. The ability of ACE2 to lend physiologic protection stems from its various functions, including metabolizing AngI to Ang1-9, which reduces ACE1 substrate; breaking AngII down, which reduces the $\mathrm{AT}_{1} \mathrm{R}$ activation; and generating Ang1-7, which is responsible for inducing cardioprotective effects (Patel et al., 2016b). Although the ACE2/Ang1-7 axis is responsible for antihypertensive effects, much of the activity of this system does not directly cause vasodilation but rather entails other mechanisms, which predominantly include downregulation of proinflammatory responses (Crackower et al., 2002). ACE2 activity decreases inflammation by maintaining the balance in RAS activity (Nehme and Zibara, 2017). In pathologies associated with increased RAS activation-e.g., hypertension, heart failure, and diabetes-ACE2 activity confers some protection by counteracting the effect of AngII activation, possibly by reducing cellular apoptosis and oxidative stress (Shenoy et al., 2010; Chang et al., 2011; Bernardi et al., 2016). Specifically, stimulating ACE2 activity decreased the levels of TNF- $\alpha$, IL- $1 \beta$, and IL- 6 in addition to increasing the expression of anti-inflammatory cytokine IL-10 in an animal model of autoimmune myocarditis (Sukumaran et al., 2011).

Significantly, ACE2 plays a key role in cellular entry for several coronaviruses, including SARS-CoV-2, and its wide distribution may support viral invasion and potential damage in susceptible organs (Hamming et al., 2004; Chen et al., 2020c; Coutard et al., 2020). Conversely, ACE2 activity is crucial in noncommunicable disorders, such as autoimmune, cardiovascular, metabolic, and gastrointestinal diseases, to mitigate many associated proinflammatory and pathogenic effects (Zhang and Wada, 2007; Perlot and Penninger, 2013; Simões e Silva et al., 2013; Patel et al., 2016b). Thus, inhibition of ACE2 as a therapeutic target against SARS-CoV-2 has been ruled out from the start. As such, ACE2 has emerged as the double-edged sword in the SARS-CoV-2 ordeal, as it is both physiologically protective and virally conducive (Zores and 
Rebeaud, 2020). Highlighting the distribution of ACE2 in the body will elucidate various tissue-specific symptoms that may arise upon viral infection. Moreover, identifying its dysregulation in patients with comorbidities may offer insight as to why coronavirus infectious disease 2019 (COVID-19) symptoms are often more severe in these individuals.

\section{ACE2 Tissue Distribution}

ACE2 is a zinc metalloproteinase transmembrane protein characterized by having several domains: a signal peptide, a carboxy peptidase active site, a transmembrane domain, and a cytoplasmic domain (Donoghue et al., 2000; Haga et al., 2008). Importantly, it has been detected in cell culture media, indicating that it likely also exists in an extracellular secreted form. The enzyme is abundantly found on the vascular endothelium, including capillaries, arterioles, arteries, venules, and veins, which embed every organ (Hamming et al., 2004). Besides vessels, ACE2 is also majorly detected in the tissues of the lung, heart, kidney, and testis (Donoghue et al., 2000). It is present on cells that have direct contact with the environment, particularly type 1 and 2 alveolar epithelial pneumocytes of the lungs (Hamming et al., 2004). Hamming et al. (2004) were able to further characterize the distribution of ACE2-like immunoreactive material in approximately 72 different human tissues obtained from autopsy specimens, including the brush boarder of the small intestine enterocytes and renal proximal tubular cells, cholangiocytes, the brain, the basolateral layer of the skin epithelium, and epithelial cells of the oral and nasal mucosa and nasopharynx. Interestingly, a recent investigation correlates ACE2 expression levels with SARS-CoV-2 viral loads in swabs from different tissues in infected individuals (Sungnak et al., 2020; Zou et al., 2020).

\section{The Effect of Comorbid ACE2 Dysregulation on COVID-19-Associated Symptoms}

Many diseases are associated with impaired ACE2 activity in the implicated organs. One of the major corollaries of this impairment is an elevated proinflammatory response (Kangussu et al., 2019; Patel et al., 2016b). Ultimately, tissue injury and fibrosis may result. Patients with underlying diseases such as hypertension, diabetes, and coronary heart diseases have been shown to have more severe COVID-19 symptoms (Guan et al., 2020; Huang et al., 2020). This may be attributed to the pre-existing proinflammatory state, which is further propelled by the cytokine storm induced by SARSCoV-2. Moreover, it can also be a consequence of an interplay with RAS and thus further loss of functional ACE2 units that are shed from the cell surface or downregulated after internalization following interaction with SARS-CoV-2 (Haga et al., 2008; Services et al., 2014; Gheblawi et al., 2020).

On the other hand, extrapulmonary symptoms in infected individuals with no known underlying diseases are increasingly emerging in patients with COVID-19. Besides pneumonia, other symptoms associated with the virus span the intestinal tract, cardiovascular system, central nervous system, and others (Fang et al., 2020; Zheng et al., 2020). We propose that the emergence of such symptoms is related to the presence of ACE2 in these specific tissues. Conversely, the disruption of ACE2 in patients with underlying diseases may contribute to the severity of symptoms detected in these individuals. Therefore, it is important to highlight the distribution of ACE2 in various organs and its dysregulation in specific diseases and to monitor related symptoms in inflicted patients.

\section{Pulmonary Disease}

The Role of ACE2 in Pulmonary Diseases. Pulmonary hypertension in rats led to an enlarged right ventricle, interstitial fibrosis, and increased pulmonary wall thickness (Ferreira et al., 2009). In tandem, renin, ACE, angiotensinogen, $\mathrm{AT}_{1} \mathrm{R}$, and proinflammatory cytokines were also elevated. These manifestations were precluded by treatment with a synthetic ACE2 activator (Ferreira et al., 2009). In a related study, rats in which pulmonary fibrosis was induced displayed reduced levels of ACE2, augmented collagen deposits, increased expression of TGF- $\beta$ and other cytokines, and elevated $\mathrm{AT}_{1} \mathrm{R}$ expression (Shenoy et al., 2010). Moreover, lung injury in ACE2-knockout mice was associated with an exacerbated reduction of exercise capacity, further impairment of lung function, and increased lung fibrosis (Li et al., 2016). This phenotype was markedly attenuated by Ang1-7 or ACE2 overexpression. These findings emphasize the integral role of ACE2 in pulmonary protection against inflammation and fibrosis. Similar findings were observed upon assessing the role of ACE2 in mouse lungs in situations of inhaled endotoxins (Sodhi et al., 2018). The loss of ACE2 expression induced an activation of des-Arg ${ }^{9}$ bradykinin/bradykinin $\mathrm{B} 1$ receptor pathway, leading to an increase in chemokines, macrophage inflammatory protein-2, TNF- $\alpha$, and neutrophil infiltration, thus exaggerating lung inflammation and injury (Sodhi et al., 2018). Even in chronic airway inflammatory conditions like asthma, Ang1-7 significantly reduced the number of autoinflammatory-related leukocytes, including macrophages, eosinophils, and neutrophils (El-Hashim et al., 2012). Ang1-7 also reduced immune cell infiltration, fibrosis, and goblet cell metaplasia, which suggests airway remodeling. As such, it becomes plausible to assume that suppression of ACE2 activity/ expression might exacerbate lung injury after viral invasion.

ACE2 and Pulmonary Symptoms in Patients with SARS-CoV-2. ACE2 is highly expressed in the lungs (Letko et al., 2020), in which $83 \%$ of ACE2-displaying pulmonary cells were alveolar cells, implicating the alveoli as a reservoir for viral invasion ( $\mathrm{Li}$ et al., 2020b). Recent investigation showed that although lung inflammatory disorders including asthma and chronic obstructive pulmonary disease are not associated with changes in ACE2 expression, smokers had increased pulmonary expression levels, further confirming the susceptibility of these patient groups (Grundy et al., 2020; Li et al., 2020a). Interestingly, this is thought to occur as a consequence of nicotine-mediated stimulation of $\alpha_{7}$-nicotinic acetylcholine receptors (Leung et al., 2020). Conversely, others propose that some of the SARS-CoV-2 proteins might carry amino acid sequences similar to those of known neurotoxins that block nicotinic acetylcholine receptors (Farsalinos et al., 2020b,c). This suggested a possible role for $\alpha_{7}$-nicotinic acetylcholine receptors as potential sites of interaction with SARS-CoV-2. As such, one might speculate that this interaction drives inflammatory cytokine production, whereby infected lung macrophage will be deprived of the anti-inflammatory effect 
exerted by nicotine-mediated activation of $\alpha_{7}$-nicotinic acetylcholine receptors on their surface (Kloc et al., 2020). If this competitive relationship between SARS-CoV-2 and nicotine on $\alpha_{7}$-nicotinic acetylcholine receptors is proven experimentally, it could potentially offer a molecular explanation for the clinical debate that nicotine, and hence tobacco smoking, might be protective against COVID-19 (Farsalinos et al., 2020a). On the other hand, the large surface area of the lungs favors their high susceptibility to inhaled viruses (Zhang et al., 2020a). Because of ACE2 abundance on pneumocytes and pulmonary vessels, massive SARS-CoV-2 entry and subsequent alveolar wall destruction is expected, contributing to the lung damage associated with COVID-19 (Hamming et al., 2004; Zhou et al., 2020b). Contrary to other coronaviruses, SARS-CoV-1 and SARS-CoV-2 have been found to decrease cell membrane-bound ACE2, which in turn promotes severe acute respiratory complications (Kuba et al., 2005; Haga et al., 2008; Ingraham et al., 2020), further alluding to the paradoxical nature of ACE2's role in the course of pulmonary infections. However, other work reports a rebound in pulmonary ACE2 expression 48 hours postinfection that was correlated to inflammatory cytokine production ( $\mathrm{Li}$ et al., 2020a), raising the question of why this induced increase in expression does not lead to the same beneficial effect associated with basal ACE2 expression/function.

Another factor that accounts for the much higher SARSCoV-2 pulmonary infectivity is that the viral entry is mediated by cellular membrane proteases (Hoffmann et al., 2020). Transmembrane protease serine 2 (TMPRSS2) is expressed in the epithelial cells in human lungs and is involved in the regulation of airway surface liquid. Previous studies have identified TMPRSS2 as a key element in SARS-CoV pathogenesis (Matsuyama et al., 2010). TMPRSS2 enhances viral entry through cleavage of ACE2 and activation of cell membrane fusion by cleaving S protein Services et al., 2014. TMPRSS2 contributes to higher levels of cytokine and chemokine production after SARS-CoV infection. In TMPRSS2knockout mice, the levels of monocyte chemoattractant-1 (MCP-1), IL-1 $\alpha$, IL-1 $\beta$, and IL-12 in the lungs induced by SARS-CoV infection were much lower (Iwata-Yoshikawa et al., 2019). A new study using primary human airway epithelial cells reported that SARS-CoV-2 viral entry is highly dependent on TMPRSS2, as the inhibition of TMPRSS2 by camostat mesylate totally inhibited viral infection (Hoffmann et al., 2020). Camostat mesylate, currently used in Japan as an antiviral drug for other indications, could be useful in patients with COVID-19 (Kawase et al., 2012; Zhou et al., 2015; Yamamoto et al., 2016). After the SARS-CoV-2-induced cytokine storm, patients usually suffer from signs of microvascular dilation, increase of pleural effusions and thickening, and fibrotic streaks, which could lead to subsequent progression into acute lung injury, ARDS, and respiratory failure (Zhang et al., 2020b; Zhou et al., 2020c).

\section{Cardiovascular Disease}

ACE2 and Cardiovascular Diseases. Chronic hypertension and myocardial infarction are associated with cardiac remodeling, a pathologic process leading to heart failure and mortality (Grobe et al., 2007; Maaliki et al., 2019). The remodeling occurs after prolonged and enhanced production of AngII, and inhibition of the ACE1/AngII/AT ${ }_{1} R$ system confers protection from these effects. In fact, induced overexpression of ACE2 reverses cardiac remodeling (Grobe et al., 2007) in a manner mediated by Ang1-7, which specifically reduced myocyte hypertrophy and interstitial fibrosis without affecting blood pressure. Furthermore, overexpression of ACE2 prevents cardiac hypertrophy in hypertensive rats (Sriramula et al., 2011). In a related study, ACE2 mRNA expression was markedly reduced in rat models of hypertension and was associated with defects in cardiac contractility, increased AngII levels, and upregulation of hypoxia-induced genes (Alaaeddine et al., 2019). Drugs used to treat hypertension, such as the $\mathrm{AT}_{1} \mathrm{R}$ blockers, upregulate myocardial expression of ACE2 and reduce levels of inflammatory markers like MCP1 , interleukins, and nuclear factor $\kappa$-light-chain enhancer of activated B cells (Sukumaran et al., 2012). The ACE1/AngII/ $\mathrm{AT}_{1} \mathrm{R}$ system also promotes atherosclerotic lesion formation, aneurysms, and proinflammatory cytokine secretion (Daugherty et al., 2000). ACE2 has been shown to counteract these effects. For example, knockout studies of ACE2 in mice led to plaque growth as well as an increase in several proinflammatory and atherogenic proteins, like adhesion molecules, IL-6, and MCP-1 (Thomas et al., 2010).

ACE2 and CVD Symptoms in Patients with COVID-19. Cases of acute cardiovascular anomalies have been reported in patients with COVID-19 that were previously healthy. Patients show high levels of troponin, creatine kinase, arrythmias, and incidences of myocardial injuries, which lead to higher rates of intensive care unit admission and mortality (Guo et al., 2020; Inciardi et al., 2020; Wang et al., 2020a). Patients with high troponin levels also had high levels of C-reactive protein, suggesting an inflammatory pathway linked to the SARS-CoV-2-induced myocardial injury (Guo et al., 2020). Thus, the myocardial injury seen could be attributed to SARS-CoV-2 direct viral entry as well as an increased production of cytokines that can result in decreased coronary blood flow and oxygen supply (Oudit et al., 2009). In addition, similar to other respiratory infections (Milbrandt et al., 2009), patients with COVID-19 demonstrate elevated D-dimer levels, which were also associated with disseminated intravascular coagulation, severe symptoms, and higher risk of mortality (Guan et al., 2020; Zhou et al., 2020a). Contributary mechanisms could include a series of inflammatoryimmunologic reactions, which could directly contribute to atherosclerotic plaque rupture, predisposing the patient to ischemia and thrombosis (Zhou et al., 2020a).

Significantly, ACE2-mediated viral endothelial entry could induce vascular disorders and an accelerated coagulation in patients with COVID-19 (Gallagher et al., 2008). Indeed, SARS-CoV-2 was shown to infect endothelial cells in different vascular beds in patients with COVID-19 (Varga et al., 2020). Treatment with clinical-grade human recombinant ACE2 precluded SARS-CoV-2 infection in blood vessel organoids, highlighting the importance of ACE2 in endothelial infection (Monteil et al., 2020). The endothelium plays a critical role in the regulation of the adherence of immune cells, capillary permeability, and clotting and platelet activation, all of which could be altered by viral infection (Dalrymple and Mackow, 2014). Under normal conditions, vascular endothelial growth factor (VEGF) induces repair of vascular damage. Hantavirus, a virus affecting the respiratory system, was shown to bind to VEGF and disengage the normal regulation of VEGF-induced permeability (Gavrilovskaya et al., 2012). A similar profile is 
encountered in patients with COVID-19. Indeed, serum VEGF levels were elevated in patients with COVID-19 (Huang et al., 2020), possibly triggered by hypoxia and inflammatory changes and contributing to increased vascular permeability and pulmonary edema. Interestingly, increased ACE2 expression was shown to reduce VEGF production in vitro and in vivo (Cheng et al., 2016), ameliorating increased vascular permeability during lung injury (Yu et al., 2016), which raises the question of whether SARS-CoV-2-induced endothelial ACE2 downregulation could underlie this observation. These findings highlight the importance of monitoring VEGF levels in patients with COVID-19 and also suggest a possibility of introducing treatment modalities to target VEGF responses. Bevacizumab, a humanized monoclonal anti-VEGF antibody, is currently being studied for a potential beneficial effect in reducing lung injury due to increased vascular permeability (ClinicalTrials.gov: NCT04275414) (clinicaltrials.gov/ct2/ show/NCT04275414, 2020).

On the other hand, accumulating evidence indicates an association between existing cardiovascular and metabolic disease with further progression of severe COVID-19 complications (Liu et al., 2020a; Rodriguez-Morales et al., 2020; Wehbe et al., 2020; Zhou et al., 2020a). Higher mortality rates and progression of ARDS were reported in patients with hypertension, diabetes, and coronary artery diseases (Wu et al., 2020; Wu and McGoogan, 2020). This could be attributed to stimulation of immunoinflammatory pathway, dysregulation of RAS, and most importantly, viral entry through upregulated ACE2, as previous work showed that patients with heart failure had higher ventricular ACE2 expression levels (Zisman et al., 2003). Indeed, a recent study reported that patients with COVID-19 and heart failure had higher cardiac ACE2 expression (Chen et al., 2020a). Specifically, higher ACE2 expression was observed in cardiac pericytes, raising the possibility that cardiac injury could be initiated by microvascular dysfunction. Moreover, ACE2 expression in vascular endothelial cells could facilitate localized vascular injury and subsequent viral spread. As such, in situations of altered vascular function, vascular inflammation and/or increase in VEGF, SARS-CoV-2 vascular viral entry, and viral spread could be aggravated.

\section{Inflammatory Disease: Obesity, Diabetes, and Autoimmune Disorders}

ACE2 activity has been detected in macrophages, in which its deficiency led to an increased production of AngII; proinflammatory cytokines, like TNF- $\alpha$, MCP-1, IL-6, and matrix metallopeptidase-9; and endothelial adhesion molecules (Thomas et al., 2010; Thatcher et al., 2011). Importantly, overexpression of ACE2 by macrophages significantly reduced their MCP-1 production (Guo et al., 2008), and Ang1-7 treatment decreased macrophage inflammatory response (Souza and Costa-Neto, 2012). These findings further support the vital role of ACE2 in relieving the proinflammatory response; thus, both low- and high-grade inflammatory conditions could affect the pathogenesis of COVID-19.

Interestingly, obesity is associated with increased RAS activity in adipose tissue (Yvan-Charvet and QuignardBoulangé, 2011) together with increased macrophage infiltration (Weisberg et al., 2003). Adipose tissue macrophages in obesity tend to acquire macrophage (M1) polarization with increased expression of proinflammatory cytokines (Lumeng et al., 2007). Under such circumstances, adipose inflammation in obesity contributes to insulin resistance, glucose intolerance, and cardiovascular dysfunction (Jiao and $\mathrm{Xu}, 2008$; Elkhatib et al., 2019). Interestingly, ACE2 deficiency enhanced M1 polarization of adipose tissue macrophages, increased adipose tissue inflammation, exacerbated the metabolic dysfunction, and worsened the associated cardiovascular function in diet-induced obesity (Thatcher et al., 2012; Patel et al., 2016a). Indeed, recent evidence implicates obesity as a risk factor for severe ARDS in patients with COVID-19 (Simonnet et al., 2020). Whereas no change in adipose tissue ACE2 expression levels was observed in patients with obesity compared with lean individuals (Pinheiro et al., 2017), the increased disease severity could be attributed to the overall inflammatory state that results from an obesity-triggered systemic RAS imbalance (Engeli et al., 2005).

Moreover, functional and clinical evidence supports the role of vascular inflammation induced by metabolic diseases in vascular impairment and CVD (Assar et al., 2016; Ormazabal et al., 2018). Patients with type 2 diabetes mellitus have reduced levels of ACE2 expression in various organs, which correlates with inflammatory changes especially in the kidney (Bindom and Lazartigues, 2009). Along the same lines, high levels of VEGF were observed that were correlated with high fasting blood glucose and glycosylated hemoglobin (HbA1c) levels (Zhang et al., 2018). Increases in VEGF reflected the severity of endothelial dysfunction in patients with diabetes and may lead to microvascular complications. In addition, higher levels of VEGF are associated with diabetes-induced central and peripheral neuropathy (Atif et al., 2017; Jerić et al., 2017; Tang et al., 2018). Collectively, vascular inflammation in patients with CVD and higher expression of VEGF in patients with diabetes could be additional factors to enhance viral entry and viral spread, which consequently increase COVID-19 severity in those patients. It is noteworthy that increased usage of VEGF inhibitors could induce cardiovascular and nephrological consequences; as such, extreme care should be taken in treatment with such patients (Kikuchi et al., 2019). Moreover, it is noteworthy that patients who previously recovered from SARS-CoV-1 infection reported high blood pressure as well as altered metabolism 12 years later (Wu et al., 2017). Knowing the similarities between SARS-CoV-1 and -2, a similar profile could also occur in patients with COVID-19.

ACE2 is also implicated in the autoimmune disease of rheumatoid arthritis. Mouse models of antigen-induced arthritis portrayed elevated levels of neutrophils in the knee joints, and treatments with Ang1-7 or its analog, AVE0991, were able to reduce neutrophil migration in joints and periarticular tissue (da Silveira et al., 2010). Likewise, the elevated levels of proinflammatory cytokines TNF- $\alpha$, chemokine (C-X-C motif) ligand, and IL-1 $\beta$ were reduced by Ang1-7 treatment together with hypernociception, the pain index of arthritis (da Silveira et al., 2010). Interestingly, this effect was not mediated by hypotensive or vasodilatory actions. Thus, Ang1-7 is able to mediate these effects by inhibiting local production of cytokines and, importantly, by hindering leukocyte-endothelium adhesion and rolling on the microvasculature of the knee joint. Importantly, Ang1-7 receptors have been detected on microvessels as well as leukocytes (Nie et al., 2009). These findings suggest that loss of ACE2 activity in 
patients with arthritis may inflame symptoms and cytokine production. Significantly, a recent meta-analysis showed some indication that autoimmune diseases might be associated with an increased risk of COVID-19 severity and mortality (Liu et al., 2020b); on the other hand, emerging reports indicate that SARS-CoV-2 infection precedes the development of various autoimmune disorders (Galeotti and Bayry, 2020). In either case, the role of ACE2 expression or activity alterations has not been examined.

\section{Renal Disease}

ACE2 in Renal Disease. ACE2 is abundantly expressed on the vascular endothelium supplying the kidneys and on the tubular and glomerular epithelium (Lely et al., 2004). Mice lacking ACE2 develop late-onset nephrotic glomerulosclerosis (Oudit et al., 2006) and more profound diabetic renal injury (Wong et al., 2007), where ACE2 activity was shown to be protective by reducing local AngII levels (Batlle et al., 2012). Indeed, in a related study of diabetic mice, RAS imbalance involving ACE2 downregulation was found to be involved in renal damage mediated via elevated reactive oxygen species (Chang et al., 2011). Importantly, the renoprotective effects of ACE2 are not only restricted to chronic disorders. While renal ischemia and reperfusion trigger acute kidney injury via activation of inflammatory cascades involving increased migration of leukocytes and release of cytokines, treatment with the Ang1-7 analog AVE0991 reduced renal injury and inhibited leukocyte migration in mice post-ischemia reperfusion (Barroso et al., 2012). These findings broadly categorize the ACE2 axis once again as anti-inflammatory. However, the role of ACE2/Ang1-7 appears to be rather complex and should be approached with caution, as other studies have conversely demonstrated that this pathway may contribute to certain forms of kidney injury in diabetes, including fibrogenesis and renal hypertrophy (Tikellis et al., 2008), possibly affected by differences in disease stage, locally activated signaling pathways, and dosages of the activating or inhibiting agents used (Zimmerman and Burns, 2012).

ACE2 and Renal Symptoms in Patients with SARS-CoV-2. Acute kidney injury was identified in up to $25 \%$ of patients admitted with COVID-19 (Fanelli et al., 2020), representing a higher mortality risk in these patients (Wilson and Calfee, 2020). A similar profile was seen in two other studies in which patients showing progressive increases in blood urea nitrogen and creatinine had higher mortality rates (Chen et al., 2020b; Wang et al., 2020a). The mechanism behind this renal injury could be multifactorial. Although ischemic injury and inflammatory cytokines are likely to contribute to renal damage, direct SARS-CoV-2 entry through ACE2 to the renal cells could still be a major factor. SARSCoV-2 entry in a human kidney cell line required priming by both TMPRSS2 and the endosomal cysteine proteases cathepsin B and L (Hoffmann et al., 2020). However, viral entry in ACE2-expressing HEK293 cells was reported to be mediated through endocytosis in which other proteins, such as PIKfyve, (Phosphoinositide kinase, FYVE-type zinc finger containing phosphatidylinositol-3-phosphate/phosphatidylinositol 5kinase type III) two pore segment channel 2 , and cathepsin $\mathrm{L}$, were found essential for virus entry (Ou et al., 2020). Significantly, a recent study showed cellular damage and direct ultrastructural evidence of viral infection in proximal tubular epithelial cells in postmortem examination of a patient with COVID-19 and acute kidney injury (Farkash et al., 2020). Yet other studies argue against a causal relationship between COVID-19 infection and acute kidney injury (Wang et al., 2020b). Indeed, the same factors that contribute to SARS-CoV2 infection severity and involve alteration of ACE2 activity/ expression, including age, obesity, and diabetes, contribute to increased risk of acute renal dysfunction (Fanelli et al., 2020), making the establishment of causal relationships and the examination of a role for ACE2 difficult in this context.

\section{The Reproductive System}

ACE2 in Reproductive Diseases. Although ACE1, AngII, $\mathrm{AT}_{1} \mathrm{R}, \mathrm{AT}_{2} \mathrm{R}$, ACE2, Ang1-7, and Ang1-7 receptors are all involved in the reproductive physiology in both males and females, ACE2 was found to play an important role in the testis, with expression specifically enriched in Leydig cells and cells in the seminiferous tubules (Donoghue et al., 2000; Pan et al., 2013). In males, ACE1/AngII and ACE2/Ang1-7 balance drives optimal male fertility, including steroidogenesis, epididymal contractility, and sperm cell function. Males with impaired spermatogenesis do not have detected levels of Ang1-7 or Ang1-7 receptors in seminiferous tubules compared with healthy males (Reis et al., 2010). Also, lower levels of ACE2, Ang1-7, and Ang1-7 receptors in the testis are correlated to severe impairment in spermatogenesis and lower testicular weight (Reis et al., 2010). ACE2 is specifically implicated in spermatogenesis because of its presence in Leydig cells, which produce sex hormones. Moreover, ACE2 is being increasingly considered as a therapeutic mechanism to improve male fertility (Pan et al., 2013). In addition, the expression of ACE2, Ang1-7, and Ang1-7 receptors in human ovaries is directly affected by gonadotropin, suggesting an important role in ovarian physiology, follicular development, and ovulation (Pereira et al., 2009; Reis et al., 2011). Collectively, disruption in ACE2 in male and female reproductive cells may contribute to reproductive impairments and polycystic ovarian syndrome, respectively. Furthermore, its presence within the testes makes them vulnerable to possible damage by SARS-CoV-2.

ACE2 and Reproductive Impairment in Patients with SARS-CoV-2. SARS-CoV-induced viral testicular tissue damage has been reported. SARS-CoV leads to germ destruction, loss of spermatozoon in seminiferous tubules, and leukocyte infiltration (Xu et al., 2006). The possibility of viral orchitis after SARS-CoV-2 infection potentially leading to testicular damage and infertility remains high (Cardona Maya et al., 2020). As such, it is recommended that proper care is given to male patients with COVID-19 to guard against possible orchitis, and follow-up in males recovering from COVID-19 is equally important. Furthermore, exacerbation of polycystic ovarian syndrome symptoms in females may also need proper follow-up.

\section{The Digestive System}

ACE2 and the Digestive System. Although ACE2 is a key component of the RAS system, it has an independent role in the gut. ACE2 is necessary for the expression of transporters of neutral amino acids in the small intestine (Hashimoto et al., 2012; Perlot and Penninger, 2013). Furthermore, ACE2 has been shown to confer protection against 
colitis. This was also directly correlated with a reduced uptake of tryptophan, one of the main functions of ACE2 in the gut. A reduction in tryptophan results in a reduction in the mammalian target of rapamycin pathway in the small intestine. This impairs the expression of antimicrobial peptides, leading to an altered intestinal microbiome and thus an increased susceptibility to colitis (Perlot and Penninger, 2013). Hence, ACE2 has a key role in maintaining a protective healthy biome in the gut, and its function involves a mammalian target of rapamycin pathway.

ACE2 and Digestive Impairment in Patients with SARS-CoV-2. Reports from Wuhan highlighted the enteric involvement of COVID-19: $2 \%-10 \%$ of patients with COVID19 initially presented to hospitals with gastrointestinal symptoms, such as diarrhea, abdominal pain, and vomiting (Chen et al., 2020b; Yang et al., 2020). Patients expressed symptoms 1 to 2 days prior to the development of respiratory symptoms and fever. Moreover, patients admitted to intensive care units were more likely to report abdominal pain and anorexia (Wang et al., 2020a). The intestine represents one of the biggest immune system compartments and is highly vascularized and innervated. Previous studies reported that the gut impacts the viral immune and neuronal systems and also affects pulmonary function (Mowat and Agace, 2014; Shenoy et al., 2014). In fact, the progression of intestinal infection, inflammation, and subsequent live virus emergence in the lungs suggests the development of sequential respiratory infection. Intestinal cells are highly permissive to coronaviruses regardless of the stage of cell differentiation, suggesting a high sensitivity of the intestinal epithelial cells to these viruses (Cinatl et al., 2004; Zhou et al., 2017). Furthermore, ACE2 is expressed in the oral cavity, particularly in epithelial cells of the tongue. Also, lymphocytes in the oral cavity express ACE2 receptors in a similar density as those in the lungs (Xu et al., 2020). The stomach and the esophagus have not yet displayed infected epithelial cells. SARS-CoV-2 infection could have been initiated by eating raw food from the Wuhan market, the center of coronavirus outbreak. Yet, ACE2 being located in the basolateral membrane of the oral mucosa makes the viral uptake via this route less likely to be efficient. However, its presence on the apical surface of the enterocytes and the detection of the virus in stool samples provides a possible explanation and highlights the possibility of fecal-to-oral transmission, as stated by previous studies (Yeo et al., 2020).

\section{The Bile Duct}

ACE2 and Biliary Impairment in Patients with SARS-CoV-2. The possible involvement of hepatotoxicity in patients with COVID-19 is questionable. Liver injury is found to be more prevalent in severe than in mild cases of COVID-19, and significant increases in liver enzymes and bilirubin were reported in 20\%-37\% of cases (Chen et al., 2020b; Huang et al., 2020). Taking this into account, it is not clear whether liver injury in patients with COVID-19 is mainly due to direct entry of the virus into liver cells or induced by certain drugs after treatment. ACE2 has not been detected on hepatocytes but rather on cholangiocytes of the bile ducts (Hamming et al., 2004). However, the role of ACE2 in liver disease is of great importance, as it participates in the regulation of liver inflammation, tissue remodeling, and liver fibrosis (Rajapaksha et al.,
2019). The protective pathway of ACE2 is thought to be mediated through a significant reduction in AngII-induced fibrosis, TGF- $\beta$, and NADPH oxidase (Rajapaksha et al., 2019). A study by Chai et al. identified cholangiocyte-specific expression of ACE2, which could have been a possible route of SARS-CoV-2 entry and hence could lead to profound liver toxicity in patients with COVID-19 (X. Chai et al., preprint, DOI: https://doi.org/10.1101/2020.02.03.931766). Moreover, ACE2 expression and activity were shown to be induced as a response to chronic liver injury (Osterreicher et al., 2009). As such, this begs the question of whether patients with chronic hepatic inflammatory conditions might be at a higher risk of SARS-CoV-2-induced liver damage. Subsequently proper monitoring of liver function should be undertaken to guard against liver injury in patients with COVID-19.

\section{The Nervous System}

ACE2 and the Brain. ACE2 is also found in the brain (Xu et al., 2011). The highest activity of ACE2 in the central nervous system is detected in the hypothalamus (Xu et al., 2011). AngII has been shown to reduce levels of ACE2 expression in cerebral and medullary astrocytes, although the exact role is still elusive. Conversely, ACE2 overexpression in the paraventricular nucleus has been shown to directly impede AngII-induced hypertension (Sriramula et al., 2011). As such, aside from the local neurogenic effects, even within the brain, ACE2 can impart cardioprotective roles.

ACE2 and Central Nervous System Symptoms in Patients with SARS-CoV-2. Of the most common atypical symptoms in patients with COVID-19 are the neurologic signs, which were present in $45.5 \%$ of patients with severe cases (L. Mao et al., preprint, DOI: https://doi.org/10.1101/ 2020.02.22.20026500). In this study, headache (13.1\%), dizziness $(16.8 \%)$, and impaired consciousness (14.8\%) were the most common signs of viral neuroinvasion. Other studies also reported the prevalence of neurologic symptoms as well (Baig et al., 2020; Chen et al., 2020b; Wang et al., 2020a). Moreover, a new COVID-19 case was reported to have altered mental status that developed into hemorrhagic necrotizing encephalopathy (Poyiadji et al., 2020). Moreover, a sudden loss of smell and/or taste is common in patients infected with SARS-CoV-2, possibly occurring without any other typical symptoms, which highlights central nervous system involvement as a COVID19 manifestation (Gautier and Ravussin, 2020). Previous studies detected SARS-CoV in the brain. The virus was administered via the intranasal route, where it enters through the olfactory neurons and heavily infects several areas of the brain, including piriform and infralimbic cortices, basal ganglia, and midbrain with first- or second-order connections with the olfactory bulb (Netland et al., 2008). Other sites, including those in the brainstem, were shown to have been possibly infected via the oral route. In this study, SARS-CoV infection induced neuronal death in absence of encephalitis in mice. Moreover, SARS-CoV is thought to invade the peripheral nerve terminals and then get access to the central nervous system via the synapse-connected route (Li et al., 2012, 2013). More studies have documented the neuroinvasion of other coronaviruses, in which it was shown to spread through peripheral nerves into the medullary neurons involved in the peristaltic movement of the digestive system, leading to vomiting ( $\mathrm{Li}$ et al., 2020c). The transfer between nerves could 
be through clathrin-mediated endocytosis/exocytosis pathway (Li et al., 2013). As for SARS-CoV-2, the latency period of the virus could be sufficient for neuroinvasion. Besides, severe development of COVID-19 could be linked to neuroinvasion and subsequent dysfunction in the cardiorespiratory center in the brainstem, as reported elsewhere (Netland et al., 2008). On the other hand, in addition to viral entry to neurons via ACE2 receptors, brain ischemia could also take place as a result of downregulation of ACE2 expression (Simões E Silva et al., 2017). As such, care should be taken to guide toward proper treatment and prevention of possible neuroinvasion of SARS-CoV-2-induced cardiorespiratory failure ( $\mathrm{Li}$ et al., 2020c). Altered consciousness could be as devastating as respiratory distress syndrome.

\section{ACE2 Protein Interactions and Associated Signaling Pathways}

ACE2 Interacts with Various Proteins. It is well known now that SARS-CoV-2 and SARS-CoV share $76 \%$ amino acid identity and use ACE2 as a receptor for entry (Lu et al., 2020). The spike proteins (S proteins) of coronaviruses are responsible for attachment to target cells and cellular invasion (Fehr and Perlman, 2015). Priming of SARS-CoV S proteins by host cell proteases is fundamental for proper viral uptake (Simmons et al., 2004, 2005; Matsuyama and Taguchi, 2009). Several proteases have been previously reported to activate SARS-CoV S protein. Yet in the absence of proteases on the cell surface, SARS-CoV entry occurs through the endosomal pathway, in which $\mathrm{S}$ protein is activated by endosomal proteases. However, when proteases are expressed on the cell surface, viral replication is shown to be 100 times higher (Matsuyama et al., 2005). In the latter case, S proteins will be activated and cleaved at $\mathrm{S} 1 / \mathrm{S} 2$ and $\mathrm{S} 2^{\prime}$ site. The cleavage at S2' site exposes S2 domains and enables the partition of membrane by fusion peptide and internal fusion peptide and facilitates viral entry (Lu et al., 2015).

Although ACE2 is the receptor for SARS-CoV-1 and SARSCoV-2, there are major differences between infectivity, onset of symptoms, severity of symptoms, and mortality rate. SARSCoV-2 poses an immense challenge compared with the SARS pandemic of 2003 . Whereas a total of 8098 patients worldwide got infected with the first SARS-CoV, out of whom 774 had died (https://www.cdc.gov/sars/about/fs-sars.html), up to the time this manuscript was written, SARS-CoV-2 has resulted in over 36 million infections and over 1 million deaths. Whereas $100 \%$ of patients with SARS-CoV-1 had fever, only around $44 \%$ of individuals with SARS-CoV-2 displayed elevated temperatures. Additionally, $3.8 \%$ of patients with SARS-CoV-2 have displayed diarrhea compared with the $22 \%$ of individuals infected with SARS-CoV-1 (Huang et al., 2020). One explanation for this difference is that the $\mathrm{S}$ protein of SARS-CoV-2 binds with greater affinity to ACE2 than SARS-CoV-1. The disparity in the furin-like S2' cleavage site between SARS-CoV-1 and -2 may impart unique ACE2-protein interactions and signaling cascades that ultimately play a role in the differences noted between these two coronaviruses (Coutard et al., 2020). Because of these reasons, it is necessary to characterize established and potential interactions with the receptor.

On the apical membrane of intestinal enterocytes, ACE2 has been shown to colocalize with the broad neutral amino acid transporter $\mathrm{B}^{0} \mathrm{AT} 1$ (SLC6A19, Sodium-dependent neutral amino acid transporter) and CD13 (Jando et al., 2017). CD13 is a type II transmembrane zinc metalloprotease that catalyzes the removal of amino terminal amino acids from peptides. The expression of $\mathrm{B}^{0} \mathrm{AT} 1$ directly depends on the coexpression of ACE2. $\mathrm{B}^{0} \mathrm{AT} 1$ is also detected in the kidney proximal tubule in association with collectrin (TMEM27, transmembrane protein 27), which interestingly shares the same membrane-anchoring domain of ACE2. In this context, ACE2 is considered a dimer, and the interaction with $\mathrm{B}^{0} \mathrm{AT} 1$ suggests that $\mathrm{S}$ protein is able to bind to two sites. The collectrin-like membrane-anchoring domain in ACE2 has been shown to enable the interaction with $\mathrm{B}^{0} \mathrm{AT} 1$. Collectrin is considered a homolog of ACE2 (Zhang and Wada, 2007). Not only is it involved in amino acid uptake, but it has roles in the development of renal epithelial cilia and insulin secretion. Importantly, it can interact with the SNARE (soluble N-ethylmelamide-sensitive fusion protein attachment protein receptors) complex via snapin. SNARE is indispensable for enabling the fusion of vesicles to their target intracellular compartments and directing vesicles to the extracellular membrane, as in the case of secreting insulin (Martens and McMahon, 2008). It is worth examining the role of ACE2 in similar processes, particularly in the context of viral uptake. Although $\mathrm{B}^{0} \mathrm{AT} 1$ is not necessarily prominent in the lungs, the homology between ACE2 and collectrin may highlight similar roles for this receptor, making it prudent to delineate it in the context of viral infection.

TMPRSS2 is a type II membrane serine protease that has been shown to cleave the $\mathrm{S}$ protein to allow efficient entry (Matsuyama et al., 2010). It should be noted that HAT (histone acetyl transferase) is a similar protein that was shown to activate SARS-COV-1 but, to our knowledge, has not been confirmed in the context of SARS-COV-2. Importantly, TMPRSS2 can also cleave the ACE2 receptor, and this event is implicated in increased viral invasion. However, the processing of ACE2 does not have any effect on cleavage of the viral $S$ protein itself. Increased expression of TMPRSS2 is directly associated with increased viral entry. As such, the association of TMPRSS2 with ACE2 spurs increased viral entry by cleavage of ACE2 and enhances $\mathrm{S}$ protein membrane fusion by direct cleavage of the S protein (Services et al., 2014.

Cathepsin L is also a well studied protease in SARS-COV infections. Contrary to TMPRSS2, cathepsin L is an endosomal and lysosomal $\mathrm{pH}$-dependent protease that processes $\mathrm{S}$ protein after uptake. However, initial cleavage by TMPRSS2 is independent of cathepsin $\mathrm{L}$ and is in fact the main way of entry (Services et al., 2014.

Combination of the S protein with ACE2 also triggers processing of ACE2 by disintegrin and metallopeptidase domain $16 /$ tumor necrosis factor- $\alpha$ converting enzyme. This leads to shedding of a functional ACE2 into extracellular space and promotes uptake of SARS-CoV-1. It is likely that a similar mechanism occurs upon S protein binding of SARS-CoV-2 (Services et al., 2014.

Another protease that is worth examining is furin and its related proteins. The unique cleavage site on S2' is postulated to interact with furin or furin-like proteases, which are associated with more potent virulence. Hence, upon conducting a protein blast, we detected proteins with considerable sequence homology that may also potentially interact with the $\mathrm{S}$ protein (Table 1). 
TABLE 1

Potential proteins that may be involved in S protein processing and ACE2 interaction

\begin{tabular}{|c|c|c|c|}
\hline $\begin{array}{l}\text { Protein } \\
\text { Implicated in } \\
\text { SARS-CoV-2 } \\
\text { Entry }\end{array}$ & $\begin{array}{c}\text { BLASTp Results in } \\
\text { Human Protein Data } \\
\text { Base }\end{array}$ & $\begin{array}{l}\text { Sequence } \\
\text { Identity } \\
\text { (Filter: min } \\
\sim 50 \% \text { ) }\end{array}$ & $\begin{array}{l}\text { Relevance (UniProKb } \\
\text { Data Base) }\end{array}$ \\
\hline \multirow[t]{2}{*}{$\begin{array}{l}\text { Furin } \\
\text { protease }\end{array}$} & $\begin{array}{l}\text { Cadherin-related } \\
\text { family member } 4\end{array}$ & $55.6 \%$ & $\begin{array}{c}\text { Expressed in lung, } \\
\text { uterine tube, testis } \\
\text { (similar pattern to } \\
\text { ACE2 prominent } \\
\text { distribution) single- } \\
\text { pass transmembrane } \\
\text { protein. }\end{array}$ \\
\hline & $\begin{array}{l}\text { Isoform } 7 \text { of } \\
\text { tumor necrosis } \\
\text { factor receptor } \\
\text { superfamily } \\
\text { member } 25\end{array}$ & $50 \%$ & $\begin{array}{c}\text { Interacts with } \\
\text { receptor adapter } \\
\text { protein TRADD and } \\
\text { activates NF-kB, } \\
\text { which are involved in } \\
\text { inflammatory-induced } \\
\text { apoptosis. May play } \\
\text { a role in regulating } \\
\text { lymphocyte } \\
\text { homeostasis. }\end{array}$ \\
\hline
\end{tabular}

BLASTp, protein-protein basic local alignment research tool; NF-kB, nuclear factor $\mathrm{kB}$; TRADD, tumor necrosis factor type 1-associated DEATH domain protein

Signaling Pathways Associated with SARS-CoV-2 Entry. Not only is ACE2 the mode of entry of SARS-CoV-1 and -2 , but it is also involved in its major symptom, the untreatable ARDS. MAPK pathways involving ERK, p38, and JNK are significantly activated and associated with the process of ARDS. Lipopolysaccharide-induced lung damage is diminished upon inhibition of p38 and JNK. The activity of p38 in the lung is linked to pulmonary edema and fibrosis. In the context of the heart, it was shown that ACE2 can directly inhibit ERK, thereby reducing cardiac fibrosis. We have previously highlighted the involvement of MAPK pathways in the manifestation of cardiovascular diseases like hypertrophy and atherosclerosis, as well as the possible hijack of these pathways to assist SARS-CoV-2 host internalization and replication (Wehbe et al., 2020).

ACE2 present on microvascular endothelial cells has been shown to inhibit local ERK and JNK pathways, thereby avoiding apoptosis and inflammation under lipopolysaccharide-induced inflammatory conditions ( $\mathrm{Li}$ et al., 2016). It is worth examining whether inhibition of ACE2 to block viral entry, while infusion with Ang1-7, is sufficient to maintain the protective effect of ACE2 on various organs involved.

\section{Concluding Remarks}

SARS-CoV-2 invasion is proving to be a complex and multifaceted issue, making it difficult to quell. Much of the complexity arises from the wide physiologic distribution of its favored receptor, ACE2. Adding further insult to injury is the dual role of ACE2 in this viral dilemma. As we have demonstrated, the protective role of this receptor is important in mitigating several diseases and offering proper homeostasis. Potential therapeutic mechanisms should include ways to preserve its regulatory role while shunting downstream events that may be hijacked for viral entry. For example, further investigation in protein-protein interactions and signaling pathways associated with ACE2 may offer various perspectives on how to subvert viral-induced uptake and organ injury.

\section{Authorship Contributions}

Wrote or contributed to the writing of the manuscript: Hammoud, Wehbe, Abdelhady, Kobeissy, Eid, El-Yazbi.

\section{References}

Alaaeddine RA, Mroueh A, Gust S, Eid AH, Plane F, and El-Yazbi AF (2019) Impaired cross-talk between NO and hyperpolarization in myoendothelial feedback: a novel therapeutic target in early endothelial dysfunction of metabolic disease. Curr Opin Pharmacol 45:33-41.

Assar ME, Angulo J, and Rodríguez-Mañas L (2016) Diabetes and ageing-induced vascular inflammation. $J$ Physiol 594:2125-2146.

Atif F, Prunty MC, Turan N, Stein DG, and Yousuf S (2017) Progesterone modulates diabetes/hyperglycemia-induced changes in the central nervous system and sciatic nerve. Neuroscience 350:1-12.

Baig AM, Khaleeq A, Ali U, and Syeda H (2020) Evidence of the COVID-19 virus targeting the CNS: tissue distribution, host-virus interaction, and proposed neurotropic mechanisms. ACS Chem Neurosci 11:995-998.

Barroso LC, Silveira KD, Lima CX, Borges V, Bader M, Rachid M, Santos RA, Souza DG, Simões E Silva AC, and Teixeira MM (2012) Renoprotective effects of AVE0991, a nonpeptide mas receptor agonist, in experimental acute renal injury. Int $J$ Hypertens 2012:808726.

Batlle D, Wysocki J, Soler MJ, and Ranganath K (2012) Angiotensin-converting enzyme 2: enhancing the degradation of angiotensin II as a potential therapy for diabetic nephropathy. Kidney Int 81:520-528.

Becker BK, Wang H, and Zucker IH (2017) Central TrkB blockade attenuates ICV angiotensin II-hypertension and sympathetic nerve activity in male SpragueDawley rats. Auton Neurosci 205:77-86.

Becker BK, Wang HJ, Tian C, and Zucker IH (2015) BDNF contributes to angiotensin II-mediated reductions in peak voltage-gated $\mathrm{K}+$ current in cultured CATH.a cells. Physiol Rep 3:e12598.

Bernardi S, Michelli A, Zuolo G, Candido R, and Fabris B (2016) Update on RAAS modulation for the treatment of diabetic cardiovascular disease. J Diabetes Res 2016:8917578.

Bindom SM and Lazartigues E (2009) The sweeter side of ACE2: physiological evidence for a role in diabetes. Mol Cell Endocrinol 302:193-202.

Cardona Maya WD, Du Plessis SS, and Velilla PA (2020) SARS-CoV-2 and the testis: similarity with other viruses and routes of infection. Reprod Biomed Online 40: 763-764.

Chang SY, Chen YW, Chenier I, Tran SleM, and Zhang SL (2011) Angiotensin II type II receptor deficiency accelerates the development of nephropathy in type I diabetes via oxidative stress and ACE2. Exp Diabetes Res 2011:521076.

Chen J, Chen JK, Nagai K, Plieth D, Tan M, Lee TC, Threadgill DW, Neilson EG, and Harris RC (2012) EGFR signaling promotes TGF $\beta$-dependent renal fibrosis. J Am Soc Nephrol 23:215-224.

Chen L, Li X, Chen M, Feng Y, and Xiong C (2020a) The ACE2 expression in human heart indicates new potential mechanism of heart injury among patients infected with SARS-CoV-2. Cardiovasc Res 116:1097-1100.

Chen N, Zhou M, Dong X, Qu J, Gong F, Han Y, Qiu Y, Wang J, Liu Y, Wei Y, et al. (2020b) Epidemiological and clinical characteristics of 99 cases of 2019 novel coronavirus pneumonia in Wuhan, China: a descriptive study. Lancet 395:507-513.

Chen Y, Guo Y, Pan Y, and Zhao ZJ (2020c) Structure analysis of the receptor binding of 2019-nCoV. Biochem Biophys Res Commun 525:135-140.

Cheng Q, Zhou L, Zhou J, Wan H, Li Q, and Feng Y (2016) ACE2 overexpression inhibits acquired platinum resistance-induced tumor angiogenesis in NSCLC. Oncol Rep 36:1403-1410.

Cinatl J Jr, Hoever G, Morgenstern B, Preiser W, Vogel JU, Hofmann WK, Bauer G, Michaelis M, Rabenau HF, and Doerr HW (2004) Infection of cultured intestinal epithelial cells with severe acute respiratory syndrome coronavirus. Cell Mol Life Sci 61:2100-2112.

Coutard B, Valle C, de Lamballerie X, Canard B, Seidah NG, and Decroly E (2020) The spike glycoprotein of the new coronavirus $2019-\mathrm{nCoV}$ contains a furin-like cleavage site absent in CoV of the same clade. Antiviral Res 176:104742.

Crackower MA, Sarao R, Oudit GY, Yagil C, Kozieradzki I, Scanga SE, Oliveira-dosSantos AJ, da Costa J, Zhang L, Pei Y, et al. (2002) Angiotensin-converting enzyme 2 is an essential regulator of heart function. Nature 417:822-828.

Crowley SD, Gurley SB, Herrera MJ, Ruiz P, Griffiths R, Kumar AP, Kim HS, Smithies O, Le TH, and Coffman TM (2006) Angiotensin II causes hypertension and cardiac hypertrophy through its receptors in the kidney. Proc Natl Acad Sci USA 103:17985-17990.

Dalrymple NA and Mackow ER (2014) Virus interactions with endothelial cell receptors: implications for viral pathogenesis. Curr Opin Virol 7:134-140.

da Silveira KD, Coelho FM, Vieira AT, Sachs D, Barroso LC, Costa VV, Bretas TL, Bader M, de Sousa LP, da Silva TA, et al. (2010) Anti-inflammatory effects of the activation of the angiotensin-(1-7) receptor, MAS, in experimental models of arthritis. J Immunol 185:5569-5576.

Daugherty A, Manning MW, and Cassis LA (2000) Angiotensin II promotes atherosclerotic lesions and aneurysms in apolipoprotein E-deficient mice. J Clin Invest 105:1605-1612.

Donoghue M, Hsieh F, Baronas E, Godbout K, Gosselin M, Stagliano N, Donovan M, Woolf B, Robison K, Jeyaseelan R, et al. (2000) A novel angiotensin-converting enzyme-related carboxypeptidase (ACE2) converts angiotensin I to angiotensin 1 9. Circ Res 87:E1-E9.

El-Hashim AZ, Renno WM, Raghupathy R, Abduo HT, Akhtar S, and Benter IF (2012) Angiotensin-(1-7) inhibits allergic inflammation, via the MAS1 receptor, 
through suppression of ERK1/2- and NF-кB-dependent pathways. Br J Pharmacol 166:1964-1976.

Elkhatib MAW, Mroueh A, Rafeh RW, Sleiman F, Fouad H, Saad EI, Fouda MA Elgaddar O, Issa K, Eid AH, et al. (2019) Amelioration of perivascular adipose inflammation reverses vascular dysfunction in a model of nonobese prediabetic metabolic challenge: potential role of antidiabetic drugs. Transl Res 214:121-143.

Engeli S, Böhnke J, Gorzelniak K, Janke J, Schling P, Bader M, Luft FC, and Sharma AM (2005) Weight loss and the renin-angiotensin-aldosterone system. Hypertension 45:356-362.

Fanelli V, Fiorentino M, Cantaluppi V, Gesualdo L, Stallone G, Ronco C, and Castellano G (2020) Acute kidney injury in SARS-CoV-2 infected patients. Crit Care 24:155.

Fang L, Karakiulakis G, and Roth M (2020) Are patients with hypertension and diabetes mellitus at increased risk for COVID-19 infection? Lancet Respir Med 8:e21.

Farkash EA, Wilson AM, and Jentzen JM (2020) Ultrastructural evidence for direct renal infection with SARS-CoV-2. J Am Soc Nephrol 31:1683-1687.

Farsalinos K, Barbouni A, and Niaura R (2020a) Systematic review of the prevalence of current smoking among hospitalized COVID-19 patients in China: could nicotine be a therapeutic option? Intern Emerg Med 15:845-852.

Farsalinos K, Eliopoulos E, Leonidas DD, Papadopoulos GE, Tzartos S, and Poulas K (2020b) Nicotinic cholinergic system and COVID-19: in silico identification of an interaction between SARS-CoV-2 and nicotinic receptors with potential therapeutic targeting implications. Int J Mol Sci 21:5807.

Farsalinos K, Niaura R, Le Houezec J, Barbouni A, Tsatsakis A, Kouretas D, Vantarakis A, and Poulas K (2020c) Editorial: nicotine and SARS-CoV-2: COVID-19 may be a disease of the nicotinic cholinergic system. Toxicol Rep 7:658-663.

Fehr AR and Perlman S (2015) Coronaviruses: an overview of their replication and pathogenesis. Methods Mol Biol 1282:1-23.

Ferreira AJ, Shenoy V, Yamazato Y, Sriramula S, Francis J, Yuan L, Castellano RK, Ostrov DA, Oh SP, Katovich MJ, et al. (2009) Evidence for angiotensin-converting enzyme 2 as a therapeutic target for the prevention of pulmonary hypertension. Am J Respir Crit Care Med 179:1048-1054.

Galeotti C and Bayry J (2020) Autoimmune and inflammatory diseases following COVID-19. Nat Rev Rheumatol 16:413-414.

Gallagher PE, Ferrario CM, and Tallant EA (2008) Regulation of ACE2 in cardiac myocytes and fibroblasts. Am J Physiol Heart Circ Physiol 295:H2373-H2379.

Gautier JF and Ravussin Y (2020) A new symptom of COVID-19: loss of taste and smell. Obesity (Silver Spring) 28:848.

Gavrilovskaya I, Gorbunova E, Koster F, and Mackow E (2012) Elevated VEGF levels in pulmonary edema fluid and PBMCs from patients with acute hantavirus pulmonary syndrome. Adv Virol 2012:674360.

Gheblawi M, Wang K, Viveiros A, Nguyen Q, Zhong J-C, Turner AJ, Raizada MK Grant MB, and Oudit GY (2020) Angiotensin-converting enzyme 2: SARS-CoV-2 receptor and regulator of the renin-angiotensin system: celebrating the 20th anniversary of the discovery of ACE2. Circ Res 126:1456-1474.

Gonzalez AA, Gallardo M, Cespedes C, and Vio CP (2019) Potassium intake prevents the induction of the renin-angiotensin system and increases medullary ACE2 and COX-2 in the kidneys of angiotensin II-dependent hypertensive rats. Front Pharmacol 10:1212.

Grobe JL, Mecca AP, Lingis M, Shenoy V, Bolton TA, Machado JM, Speth RC, Raizada MK, and Katovich MJ (2007) Prevention of angiotensin II-induced cardiac remodeling by angiotensin-(1-7). Am J Physiol Heart Circ Physiol 292:H736-H742

Grundy EJ, Suddek T, Filippidis FT, Majeed A, and Coronini-Cronberg S (2020) Smoking, SARS-CoV-2 and COVID-19: a review of reviews considering implications for public health policy and practice. Tob Induc Dis 18:58-58.

Guan WJ, Ni ZY, Hu Y, Liang WH, Ou CQ, He JX, Liu L, Shan H, Lei CL, Hui DSC, et al. China Medical Treatment Expert Group for Covid-19 (2020) Clinical characteristics of coronavirus disease 2019 in China. N Engl J Med 382:1708-1720.

Guo F, Chen XL, Wang F, Liang X, Sun YX, and Wang YJ (2011) Role of angiotensin II type 1 receptor in angiotensin II-induced cytokine production in macrophages. $J$ Interferon Cytokine Res 31:351-361.

Guo T, Fan Y, Chen M, Wu X, Zhang L, He T, Wang H, Wan J, Wang X, and Lu Z (2020) Cardiovascular implications of fatal outcomes of patients with coronavirus disease 2019 (COVID-19). JAMA Cardiol 5:811-818.

Guo YJ, Li WH, Wu R, Xie Q, and Cui LQ (2008) ACE2 overexpression inhibits angiotensin II-induced monocyte chemoattractant protein-1 expression in macrophages. Arch Med Res 39:149-154.

Haga S, Yamamoto N, Nakai-Murakami C, Osawa Y, Tokunaga K, Sata T, Yamamoto N, Sasazuki T, and Ishizaka Y (2008) Modulation of TNF-alpha-converting enzyme by the spike protein of SARS-CoV and ACE2 induces TNF-alpha production and facilitates viral entry. Proc Natl Acad Sci USA 105:7809-7814.

Hamming I, Timens W, Bulthuis ML, Lely AT, Navis G, and van Goor H (2004) Tissue distribution of ACE2 protein, the functional receptor for SARS coronavirus. A first step in understanding SARS pathogenesis. J Pathol 203:631-637.

Hashimoto T, Perlot T, Rehman A, Trichereau J, Ishiguro H, Paolino M, Sigl V, Hanada T, Hanada R, Lipinski S, et al. (2012) ACE2 links amino acid malnutrition to microbial ecology and intestinal inflammation. Nature 487:477-481.

Hoch NE, Guzik TJ, Chen W, Deans T, Maalouf SA, Gratze P, Weyand C, and Harrison DG (2009) Regulation of T-cell function by endogenously produced angiotensin II. Am J Physiol Regul Integr Comp Physiol 296:R208-R216.

Hoffmann M, Kleine-Weber H, Schroeder S, Krüger N, Herrler T, Erichsen S, Schiergens TS, Herrler G, Wu NH, Nitsche A, et al. (2020) SARS-CoV-2 cell entry depends on ACE2 and TMPRSS2 and is blocked by a clinically proven protease inhibitor. Cell 181:271-280.e8.

Huang C, Wang Y, Li X, Ren L, Zhao J, Hu Y, Zhang L, Fan G, Xu J, Gu X, et al. (2020) Clinical features of patients infected with 2019 novel coronavirus in Wuhan, China. Lancet 395:497-506.

Inciardi RM, Lupi L, Zaccone G, Italia L, Raffo M, Tomasoni D, Cani DS, Cerini M, Farina D, Gavazzi E, et al. (2020) Cardiac involvement in a patient with coronavirus disease 2019 (COVID-19). JAMA Cardiol 5:819-824.
Ingraham NE, Barakat AG, Reilkoff R, Bezdicek T, Schacker T, Chipman JG, Tignanelli CJ, and Puskarich MA (2020) Understanding the renin-angiotensinaldosterone-SARS-CoV axis: a comprehensive review. Eur Respir J 56:2000912

Iwata-Yoshikawa N, Okamura T, Shimizu Y, Hasegawa H, Takeda M, and Nagata N (2019) TMPRSS2 contributes to virus spread and immunopathology in the airways of murine models after coronavirus infection. J Virol 93:e01815-e01818.

Jando J, Camargo SMR, Herzog B, and Verrey F (2017) Expression and regulation of the neutral amino acid transporter B0AT1 in rat small intestine. PLoS One 12: e0184845.

Jerić M, Vukojević K, Vuica A, and Filipović N (2017) Diabetes mellitus influences the expression of NPY and VEGF in neurons of rat trigeminal ganglion. Neuropeptides 62:57-64.

Jiao P and Xu H (2008) Adipose inflammation: cause or consequence of obesityrelated insulin resistance. Diabetes Metab Syndr Obes 1:25-31.

Kamat NV, Thabet SR, Xiao L, Saleh MA, Kirabo A, Madhur MS, Delpire E, Harrison DG, and McDonough AA (2015) Renal transporter activation during angiotensin-II hypertension is blunted in interferon- $\gamma-/$ - and interleukin-17A-/- mice. Hypertension 65:569-576.

Kangussu LM, Marzano LAS, Souza CF, Dantas CC, Miranda AS, Simões E, and Silva AC (2019) The renin-angiotensin system and the cerebrovascular diseases: experimental and clinical evidence. Protein Pept Lett 27:463-475.

Kawase M, Shirato K, van der Hoek L, Taguchi F, and Matsuyama S (2012) Simultaneous treatment of human bronchial epithelial cells with serine and cysteine protease inhibitors prevents severe acute respiratory syndrome coronavirus entry. $J$ Virol 86:6537-6545.

Kikuchi R, Stevens M, Harada K, Oltean S, and Murohara T (2019) Anti-angiogenic isoform of vascular endothelial growth factor-A in cardiovascular and renal disease. Adv Clin Chem 88:1-33.

Kloc M, Ghobrial RM, and Kubiak JZ (2020) How nicotine can inhibit cytokine storm in the lungs and prevent or lessen the severity of COVID-19 infection? Immunol Lett 224:28-29.

Kuba K, Imai Y, Rao S, Gao H, Guo F, Guan B, Huan Y, Yang P, Zhang Y, Deng W, et al. (2005) A crucial role of angiotensin converting enzyme 2 (ACE2) in SARS coronavirus-induced lung injury. Nat Med 11:875-879.

Lely AT, Hamming I, van Goor H, and Navis GJ (2004) Renal ACE2 expression in human kidney disease. J Pathol 204:587-593

Letko M, Marzi A, and Munster V (2020) Functional assessment of cell entry and receptor usage for SARS-CoV-2 and other lineage B betacoronaviruses. Nat Microbiol 5:562-569.

Leung JM, Yang CX, and Sin DD (2020) COVID-19 and nicotine as a mediator of ACE-2. Eur Respir J 55:2001261.

Li G, He X, Zhang L, Ran Q, Wang J, Xiong A, Wu D, Chen F, Sun J, and Chang C (2020a) Assessing ACE2 expression patterns in lung tissues in the pathogenesis of COVID-19. J Autoimmun 112:102463.

Li Y, Zeng Z, Cao Y, Liu Y, Ping F, Liang M, Xue Y, Xi C, Zhou M, and Jiang W (2016) Angiotensin-converting enzyme 2 prevents lipopolysaccharide-induced rat acute lung injury via suppressing the ERK1/2 and NF-KB signaling pathways. Sci Rep 6: 27911

Li Y, Zhou W, Yang L, and You R (2020b) Physiological and pathological regulation of ACE2, the SARS-CoV-2 receptor. Pharmacol Res 157:104833.

Li YC, Bai WZ, and Hashikawa T (2020c) The neuroinvasive potential of SARS-CoV2 may play a role in the respiratory failure of COVID-19 patients. J Med Virol $\mathbf{9 2}$ $552-555$

Li YC, Bai WZ, Hirano N, Hayashida T, and Hashikawa T (2012) Coronavirus infection of rat dorsal root ganglia: ultrastructural characterization of viral replication, transfer, and the early response of satellite cells. Virus Res 163:628-635.

Li YC, Bai WZ, Hirano N, Hayashida T, Taniguchi T, Sugita Y, Tohyama K, and Hashikawa T (2013) Neurotropic virus tracing suggests a membranous-coating-mediated mechanism for transsynaptic communication. J Comp Neurol $\mathbf{5 2 1}$ 203-212.

Liu K, Fang YY, Deng Y, Liu W, Wang MF, Ma JP, Xiao W, Wang YN, Zhong MH, Li $\mathrm{CH}$, et al. (2020a) Clinical characteristics of novel coronavirus cases in tertiary hospitals in Hubei Province. Chin Med J (Engl) 133:1025-1031.

Liu M, Gao Y, Zhang Y, Shi S, Chen Y, and Tian J (2020b) The association between severe or death COVID-19 and autoimmune disease: a systematic review and meta-analysis. J Infect81:e93-e95.

Lu G, Wang Q, and Gao GF (2015) Bat-to-human: spike features determining host jump' of coronaviruses SARS-CoV, MERS-CoV, and beyond. Trends Microbiol 23 $468-478$

Lu R, Zhao X, Li J, Niu P, Yang B, Wu H, Wang W, Song H, Huang B, Zhu N, et al. (2020) Genomic characterisation and epidemiology of 2019 novel coronavirus: implications for virus origins and receptor binding. Lancet 395:565-574.

Lumeng CN, Bodzin JL, and Saltiel AR (2007) Obesity induces a phenotypic switch in adipose tissue macrophage polarization. $J$ Clin Invest 117:175-184.

Maaliki D, Shaito AA, Pintus G, El-Yazbi A, and Eid AH (2019) Flavonoids in hypertension: a brief review of the underlying mechanisms. Curr Opin Pharmacol 45: $57-65$

Madhur MS, Lob HE, McCann LA, Iwakura Y, Blinder Y, Guzik TJ, and Harrison DG (2010) Interleukin 17 promotes angiotensin II-induced hypertension and vascular dysfunction. Hypertension 55:500-507.

Marshall RP (2003) The pulmonary renin-angiotensin system. Curr Pharm Des 9: 715-722.

Marshall RP, McAnulty RJ, and Laurent GJ (2000) Angiotensin II is mitogenic for human lung fibroblasts via activation of the type 1 receptor. Am J Respir Crit Care Med 161:1999-2004.

Martens S and McMahon HT (2008) Mechanisms of membrane fusion: disparate players and common principles. Nat Rev Mol Cell Biol 9:543-556.

Matsuyama S, Nagata N, Shirato K, Kawase M, Takeda M, and Taguchi F (2010) Efficient activation of the severe acute respiratory syndrome coronavirus spike protein by the transmembrane protease TMPRSS2. J Virol 84:12658-12664. 
Matsuyama S and Taguchi F (2009) Two-step conformational changes in a coronavirus envelope glycoprotein mediated by receptor binding and proteolysis. $J$ Virol 83: 11133-11141.

Matsuyama S, Ujike M, Morikawa S, Tashiro M, and Taguchi F (2005) Proteasemediated enhancement of severe acute respiratory syndrome coronavirus infection. Proc Natl Acad Sci USA 102:12543-12547.

Milbrandt EB, Reade MC, Lee M, Shook SL, Angus DC, Kong L, Carter M, Yealy DM, and Kellum JA; GenIMS Investigators (2009) Prevalence and significance of coagulation abnormalities in community-acquired pneumonia. Mol Med 15: $438-445$.

Monteil V, Kwon H, Prado P, Hagelkrüys A, Wimmer RA, Stahl M, Leopoldi A Garreta E, Hurtado Del Pozo C, Prosper F, et al. (2020) Inhibition of SARS-CoV-2 infections in engineered human tissues using clinical-grade soluble human ACE2. Cell 181:905-913.e7.

Mowat AM and Agace WW (2014) Regional specialization within the intestinal immune system. Nat Rev Immunol 14:667-685.

Nehme A and Zibara K (2017) Efficiency and specificity of RAAS inhibitors in cardiovascular diseases: how to achieve better end-organ protection? Hypertens Res 40:903-909.

Netland J, Meyerholz DK, Moore S, Cassell M, and Perlman S (2008) Severe acute respiratory syndrome coronavirus infection causes neuronal death in the absence of encephalitis in mice transgenic for human ACE2. J Virol 82:7264-7275.

Nie W, Yan H, Li S, Zhang Y, Yu F, Zhu W, Fan F, and Zhu J (2009) Angiotensin-(1-7) enhances angiotensin II induced phosphorylation of ERK1/2 in mouse bone marrow-derived dendritic cells. Mol Immunol 46:355-361.

Nistala R, Whaley-Connell A, and Sowers JR (2008) Redox control of renal function and hypertension. Antioxid Redox Signal 10:2047-2089.

Ormazabal V, Nair S, Elfeky O, Aguayo C, Salomon C, and Zuñiga FA (2018) Association between insulin resistance and the development of cardiovascular disease. Cardiovasc Diabetol 17:122.

Osterreicher CH, Taura K, De Minicis S, Seki E, Penz-Osterreicher M, Kodama Y, Kluwe J, Schuster M, Oudit GY, Penninger JM, et al. (2009) Angiotensin-converting-enzyme 2 inhibits liver fibrosis in mice. Hepatology 50:929-938.

Ou X, Liu Y, Lei X, Li P, Mi D, Ren L, Guo L, Guo R, Chen T, Hu J, et al. (2020) Characterization of spike glycoprotein of SARS-CoV-2 on virus entry and its immune cross-reactivity with SARS-CoV. Nat Commun 11:1620.

Oudit GY, Herzenberg AM, Kassiri Z, Wong D, Reich H, Khokha R, Crackower MA, Backx PH, Penninger JM, and Scholey JW (2006) Loss of angiotensin-converting enzyme-2 leads to the late development of angiotensin II-dependent glomerulosclerosis. Am J Pathol 168:1808-1820.

Oudit GY, Kassiri Z, Jiang C, Liu PP, Poutanen SM, Penninger JM, and Butany J (2009) SARS-coronavirus modulation of myocardial ACE2 expression and in flammation in patients with SARS. Eur J Clin Invest 39:618-625.

Pan PP, Zhan QT, Le F, Zheng YM, and Jin F (2013) Angiotensin-converting enzymes play a dominant role in fertility. Int $J$ Mol Sci 14:21071-21086.

Park JK, Fischer R, Dechend R, Shagdarsuren E, Gapeljuk A, Wellner M, Meiners S, Gratze P, Al-Saadi N, Feldt S, et al. (2007) p38 mitogen-activated protein kinase inhibition ameliorates angiotensin II-induced target organ damage. Hypertension 49:481-489.

Patel VB, Mori J, McLean BA, Basu R, Das SK, Ramprasath T, Parajuli N, Penninger JM, Grant MB, Lopaschuk GD, et al. (2016a) ACE2 deficiency worsens epicardial adipose tissue inflammation and cardiac dysfunction in response to diet-induced obesity. Diabetes 65:85-95

Patel VB, Zhong JC, Grant MB, and Oudit GY (2016b) Role of the ACE2/angiotensin 1-7 Axis of the renin-angiotensin system in heart failure. Circ Res 118:1313-1326.

Pellegrino PR, Schiller AM, Haack KK, and Zucker IH (2016) Central angiotensin-II increases blood pressure and sympathetic outflow via Rho kinase activation in conscious rabbits. Hypertension 68:1271-1280.

Peng H, Sarwar Z, Yang XP, Peterson EL, Xu J, Janic B, Rhaleb N, Carretero OA and Rhaleb NE (2015) Profibrotic role for interleukin-4 in cardiac remodeling and dysfunction. Hypertension 66:582-589.

Pereira VM, Reis FM, Santos RA, Cassali GD, Santos SH, Honorato-Sampaio K, and dos Reis AM (2009) Gonadotropin stimulation increases the expression of angiotensin-(1--7) and MAS receptor in the rat ovary. Reprod Sci 16:1165-1174.

Perlot T and Penninger JM (2013) ACE2 - from the renin-angiotensin system to gut microbiota and malnutrition. Microbes Infect 15:866-873.

Pinheiro TA, Barcala-Jorge AS, Andrade JMO, Pinheiro TA, Ferreira ECN, Crespo TS, Batista-Jorge GC, Vieira CA, Lelis DF, Paraíso AF, et al. (2017) Obesity and malnutrition similarly alter the renin-angiotensin system and inflammation in mice and human adipose. $J$ Nutr Biochem 48:74-82.

Poyiadji N, Shahin G, Noujaim D, Stone M, Patel S, and Griffith B (2020) COVID-19associated acute hemorrhagic necrotizing encephalopathy: imaging features. $R a$ diology 296:E119-E120.

Rajapaksha IG, Gunarathne LS, Asadi K, Cunningham SC, Sharland A, Alexander IE, Angus PW, and Herath CB (2019) Liver-targeted angiotensin converting en zyme 2 therapy inhibits chronic biliary fibrosis in multiple drug-resistant gene 2 knockout mice. Hepatol Commun 3:1656-1673.

Reis AB, Araújo FC, Pereira VM, Dos Reis AM, Santos RA, and Reis FM (2010) Angiotensin (1-7) and its receptor Mas are expressed in the human testis: implications for male infertility. J Mol Histol 41:75-80.

Reis FM, Bouissou DR, Pereira VM, Camargos AF, dos Reis AM, and Santos RA (2011) Angiotensin-(1-7), its receptor Mas, and the angiotensin-converting enzyme type 2 are expressed in the human ovary. Fertil Steril 95:176-181.

Rodriguez-Morales AJ, Cardona-Ospina JA, Gutiérrez-Ocampo E, Villamizar-Peña R, Holguin-Rivera Y, Escalera-Antezana JP, Alvarado-Arnez LE, Bonilla-Aldana DK, Franco-Paredes C, Henao-Martinez AF, et al.; Latin American Network of Coronavirus Disease 2019-COVID-19 Research (LANCOVID-19). Electronic address: https://www.lancovid.org (2020) Clinical, laboratory and imaging features of COVID-19: a systematic review and meta-analysis. Travel Med Infect Dis 34: 101623.
Rupérez M, Sánchez-López E, Blanco-Colio LM, Esteban V, Rodríguez-Vita J, Plaza JJ, Egido J, and Ruiz-Ortega M (2005) The Rho-kinase pathway regulates angiotensin II-induced renal damage. Kidney Int Suppl S39-S45.

Rüster C and Wolf G (2011) Angiotensin II as a morphogenic cytokine stimulating renal fibrogenesis. J Am Soc Nephrol 22:1189-1199.

Santos RA and Ferreira AJ (2007) Angiotensin-(1-7) and the renin-angiotensin system. Curr Opin Nephrol Hypertens 16:122-128.

Services A, Hofmann-Winkler H, Gierer S, Liepold T, Jahn O, and Pöhlmann S (2014) TMPRSS2 and ADAM17 cleave ACE2 differentially and only proteolysis by TMPRSS2 augments entry driven by the severe acute respiratory syndrome coronavirus spike protein. J Virol 88:1293-1307.

Shenoy V, Ferreira AJ, Qi Y, Fraga-Silva RA, Díez-Freire C, Dooies A, Jun JY, Sriramula S, Mariappan N, Pourang D, et al. (2010) The angiotensin-converting enzyme 2/angiogenesis-(1-7)/Mas axis confers cardiopulmonary protection against lung fibrosis and pulmonary hypertension. Am J Respir Crit Care Med 182: 1065-1072.

Shenoy V, Kwon KC, Rathinasabapathy A, Lin S, Jin G, Song C, Shil P, Nair A, Qi Y, $\mathrm{Li} \mathrm{Q}$, et al. (2014) Oral delivery of Angiotensin-converting enzyme 2 and Angiotensin-(1-7) bioencapsulated in plant cells attenuates pulmonary hypertension. Hypertension 64:1248-1259.

Simmons G, Gosalia DN, Rennekamp AJ, Reeves JD, Diamond SL, and Bates P (2005) Inhibitors of cathepsin L prevent severe acute respiratory syndrome coronavirus entry. Proc Natl Acad Sci USA 102:11876-11881.

Simmons G, Reeves JD, Rennekamp AJ, Amberg SM, Piefer AJ, and Bates P (2004) Characterization of severe acute respiratory syndrome-associated coronavirus (SARS-CoV) spike glycoprotein-mediated viral entry. Proc Natl Acad Sci USA 101: $4240-4245$

Simões e Silva AC, Silveira KD, Ferreira AJ, and Teixeira MM (2013) ACE2, angiotensin-(1-7) and Mas receptor axis in inflammation and fibrosis. $\mathrm{Br}$ J Pharmacol 169:477-492.

Simões E Silva AC, Miranda AS, Rocha NP, and Teixeira AL (2017) Renin angiotensin system in liver diseases: friend or foe? World J Gastroenterol 23:3396-3406.

Simonnet A, Chetboun M, Poissy J, Raverdy V, Noulette J, Duhamel A, Labreuche J, Mathieu D, Pattou F, and Jourdain M; LICORN and the Lille COVID-19 and Obesity study group (2020) High prevalence of obesity in severe acute respiratory syndrome coronavirus-2 (SARS-CoV-2) requiring invasive mechanical ventilation. Obesity (Silver Spring) 28:1195-1199.

Sodhi CP, Wohlford-Lenane C, Yamaguchi Y, Prindle T, Fulton WB, Wang S, McCray PB Jr, Chappell M, Hackam DJ, and Jia H (2018) Attenuation of pulmonary ACE2 activity impairs inactivation of des-Arg ${ }^{9}$ bradykinin/BKB1R axis and facilitates LPS-induced neutrophil infiltration. Am J Physiol Lung Cell Mol Physiol 314: L17-L31.

Souza LL and Costa-Neto CM (2012) Angiotensin-(1-7) decreases LPS-induced inflammatory response in macrophages. J Cell Physiol 227:2117-2122.

Sparks MA, Crowley SD, Gurley SB, Mirotsou M, and Coffman TM (2014) Classical Renin-Angiotensin system in kidney physiology. Compr Physiol 4:1201-1228.

Sriramula S, Cardinale JP, Lazartigues E, and Francis J (2011) ACE2 overexpression in the paraventricular nucleus attenuates angiotensin II-induced hypertension. Cardiovasc Res 92:401-408.

Sukumaran V, Veeraveedu PT, Gurusamy N, Lakshmanan AP, Yamaguchi K, Ma M, Suzuki K, Kodama M, and Watanabe K (2012) Telmisartan acts through the modulation of ACE-2/ANG 1-7/mas receptor in rats with dilated cardiomyopathy induced by experimental autoimmune myocarditis. Life Sci 90:289-300.

Sukumaran V, Veeraveedu PT, Gurusamy N, Yamaguchi K, Lakshmanan AP, Ma M, Suzuki K, Kodama M, and Watanabe K (2011) Cardioprotective effects of telmisartan against heart failure in rats induced by experimental autoimmune myocarditis through the modulation of angiotensin-converting enzyme-2/angiotensin 1 7/mas receptor axis. Int J Biol Sci 7:1077-1092.

Sungnak W, Huang N, Bécavin C, Berg M, Queen R, Litvinukova M, Talavera-López C, Maatz H, Reichart D, Sampaziotis F, et al.; HCA Lung Biological Network (2020) SARS-CoV-2 entry factors are highly expressed in nasal epithelial cells together with innate immune genes. Nat Med 26:681-687.

Tang W, Chen X, Liu H, Lv Q, Zou J, Shi Y, and Liu Z (2018) Expression of Nrf2 promotes schwann cell-mediated sciatic nerve recovery in diabetic peripheral neuropathy. Cell Physiol Biochem 46:1879-1894.

Thatcher SE, Gupte M, Hatch N, and Cassis LA (2012) Deficiency of ACE2 in bonemarrow-derived cells increases expression of TNF- $\alpha$ in adipose stromal cells and augments glucose intolerance in obese C57BL/6 mice. Int $J$ Hypertens 2012 762094.

Thatcher SE, Zhang X, Howatt DA, Lu H, Gurley SB, Daugherty A, and Cassis LA (2011) Angiotensin-converting enzyme 2 deficiency in whole body or bone marrowderived cells increases atherosclerosis in low-density lipoprotein receptor-/- mice. Arterioscler Thromb Vasc Biol 31:758-765.

Thomas MC, Pickering RJ, Tsorotes D, Koitka A, Sheehy K, Bernardi S, Toffoli B, Nguyen-Huu TP, Head GA, Fu Y, et al. (2010) Genetic Ace2 deficiency accentuates vascular inflammation and atherosclerosis in the ApoE knockout mouse. Circ Res 107:888-897.

Tikellis C, Bialkowski K, Pete J, Sheehy K, Su Q, Johnston C, Cooper ME, and Thomas MC (2008) ACE2 deficiency modifies renoprotection afforded by ACE inhibition in experimental diabetes. Diabetes 57:1018-1025.

Uhal BD, Kim JK, Li X, and Molina-Molina M (2007) Angiotensin-TGF-beta 1 crosstalk in human idiopathic pulmonary fibrosis: autocrine mechanisms in myofibroblasts and macrophages. Curr Pharm Des 13:1247-1256.

Uhal BD, Li X, Piasecki CC, and Molina-Molina M (2012) Angiotensin signalling in pulmonary fibrosis. Int $J$ Biochem Cell Biol 44:465-468.

Uhal BD, Li X, Xue A, Gao X, and Abdul-Hafez A (2011) Regulation of alveolar epithelial cell survival by the ACE-2/angiotensin 1-7/Mas axis. Am J Physiol Lung Cell Mol Physiol 301:L269-L274.

van Twist DJ, Kroon AA, and de Leeuw PW (2014) Angiotensin-(1-7) as a strategy in the treatment of hypertension? Curr Opin Nephrol Hypertens 23:480-486. 
Varga Z, Flammer AJ, Steiger P, Haberecker M, Andermatt R, Zinkernagel AS, Mehra MR, Schuepbach RA, Ruschitzka F, and Moch H (2020) Endothelial cell infection and endotheliitis in COVID-19. Lancet 395:1417-1418.

Wang D, Hu B, Hu C, Zhu F, Liu X, Zhang J, Wang B, Xiang H, Cheng Z, Xiong Y, et al. (2020a) Clinical characteristics of 138 hospitalized patients with 2019 novel coronavirus-infected pneumonia in Wuhan, China. Jama 323:1061-1069.

Wang L, Li X, Chen H, Yan S, Li D, Li Y, and Gong Z (2020b) Coronavirus disease 19 infection does not result in acute kidney injury: an analysis of 116 hospitalized patients from Wuhan, China. Am J Nephrol 51:343-348.

Wehbe Z, Hammoud S, Soudani N, Zaraket H, El-Yazbi A, and Eid AH (2020) Molecular insights into SARS COV-2 interaction with cardiovascular disease: role of RAAS and MAPK signaling. Front Pharmacol 11:836.

Weisberg SP, McCann D, Desai M, Rosenbaum M, Leibel RL, and Ferrante AW Jr (2003) Obesity is associated with macrophage accumulation in adipose tissue. $J$ Clin Invest 112:1796-1808.

Wilson JG and Calfee CS (2020) ARDS subphenotypes: understanding a heterogeneous syndrome. Crit Care 24:102.

Wong DW, Oudit GY, Reich H, Kassiri Z, Zhou J, Liu QC, Backx PH, Penninger JM, Herzenberg AM, and Scholey JW (2007) Loss of angiotensin-converting enzyme-2 (Ace2) accelerates diabetic kidney injury. Am J Pathol 171:438-451.

Wu C, Chen X, Cai Y, Xia J, Zhou X, Xu S, Huang H, Zhang L, Zhou X, Du C, et al. (2020) Risk factors associated with acute respiratory distress syndrome and death in patients with coronavirus disease 2019 pneumonia in Wuhan, China. JAMA Intern Med 180:934-943.

Wu Q, Zhou L, Sun X, Yan Z, Hu C, Wu J, Xu L, Li X, Liu H, Yin P, et al. (2017) Altered lipid metabolism in recovered SARS patients twelve years after infection. Sci Rep 7:9110.

Wu Z and McGoogan JM (2020) Characteristics of and important lessons from the coronavirus disease 2019 (COVID-19) outbreak in China: summary of a report of 72314 cases from the Chinese center for disease control and prevention. Jama 323 $1239-1242$

Xia H, Sriramula S, Chhabra KH, and Lazartigues E (2013) Brain angiotensinconverting enzyme type 2 shedding contributes to the development of neurogenic hypertension. Circ Res 113:1087-1096.

Xu H, Zhong L, Deng J, Peng J, Dan H, Zeng X, Li T, and Chen Q (2020) High expression of ACE2 receptor of $2019-\mathrm{nCoV}$ on the epithelial cells of oral mucosa. Int J Oral Sci 12:8.

Xu J, Qi L, Chi X, Yang J, Wei X, Gong E, Peh S, and Gu J (2006) Orchitis: a complication of severe acute respiratory syndrome (SARS). Biol Reprod 74:410-416.

Xu P, Sriramula S, and Lazartigues E (2011) ACE2/ANG-(1-7)/Mas pathway in the brain: the axis of good. Am J Physiol Regul Integr Comp Physiol 300:R804-R817.

Yamamoto M, Matsuyama S, Li X, Takeda M, Kawaguchi Y, Inoue JI, and Matsuda Z (2016) Identification of nafamostat as a potent inhibitor of Middle East respiratory syndrome coronavirus S protein-mediated membrane fusion using the split-protein-based cell-cell fusion assay. Antimicrob Agents Chemother 60:6532-6539.

Yang X, Yu Y, Xu J, Shu H, Xia J, Liu H, Wu Y, Zhang L, Yu Z, Fang M, et al. (2020 Clinical course and outcomes of critically ill patients with SARS-CoV-2 pneumonia in Wuhan, China: a single-centered, retrospective, observational study. Lancet Respir Med 8:475-481.

Ye J, Ji Q, Liu J, Liu L, Huang Y, Shi Y, Shi L, Wang M, Liu M, Feng Y, et al. (2017) Interleukin 22 promotes blood pressure elevation and endothelial dysfunction in angiotensin II-treated mice. J Am Heart Assoc 6:e005875.

Yeo C, Kaushal S, and Yeo D (2020) Enteric involvement of coronaviruses: is faecal-oral transmission of SARS-CoV-2 possible? Lancet Gastroenterol Hepatol 5:335-337.

Young CN, Morgan DA, Butler SD, Rahmouni K, Gurley SB, Coffman TM, Mark AL, and Davisson RL (2015) Angiotensin type 1a receptors in the forebrain subfornical organ facilitate leptin-induced weight loss through brown adipose tissue thermogenesis. Mol Metab 4:337-343.

Yu X, Lin Q, Qin X, Ruan Z, Zhou J, Lin Z, Su Y, Zheng J, and Liu Z (2016) ACE2 antagonizes VEGFa to reduce vascular permeability during acute lung injury. Cell Physiol Biochem 38:1055-1062.
Yu Y, Xue BJ, Wei SG, Zhang ZH, Beltz TG, Guo F, Johnson AK, and Felder RB (2015) Activation of central PPAR- $\gamma$ attenuates angiotensin II-induced hypertension. Hypertension 66:403-411.

Yvan-Charvet L and Quignard-Boulangé A (2011) Role of adipose tissue reninangiotensin system in metabolic and inflammatory diseases associated with obesity. Kidney Int 79:162-168.

Zaman MA, Oparil S, and Calhoun DA (2002) Drugs targeting the renin-angiotensinaldosterone system. Nat Rev Drug Discov 1:621-636.

Zhang H, Penninger JM, Li Y, Zhong N, and Slutsky AS (2020a) Angiotensinconverting enzyme 2 (ACE2) as a SARS-CoV-2 receptor: molecular mechanisms and potential therapeutic target. Intensive Care Med 46:586-590.

Zhang Q, Fang W, Ma L, Wang ZD, Yang YM, and Lu YQ (2018) VEGF levels in plasma in relation to metabolic control, inflammation, and microvascular complications in type-2 diabetes: a cohort study. Medicine (Baltimore) 97: $\mathrm{e} 0415$.

Zhang R, Wang X, Ni L, Di X, Ma B, Niu S, Liu C, and Reiter RJ (2020b) COVID-19: melatonin as a potential adjuvant treatment. Life Sci 250:117583.

Zhang Y and Wada J (2007) Collectrin, a homologue of ACE2, its transcriptional control and functional perspectives. Biochem Biophys Res Commun 363:1-5.

Zheng YY, Ma YT, Zhang JY, and Xie X (2020) COVID-19 and the cardiovascular system. Nat Rev Cardiol 17:259-260.

Zhou F, Yu T, Du R, Fan G, Liu Y, Liu Z, Xiang J, Wang Y, Song B, Gu X, et al. (2020a) Clinical course and risk factors for mortality of adult inpatients with COVID-19 in Wuhan, China: a retrospective cohort study. Lancet 395: 1054-1062.

Zhou J, Li C, Zhao G, Chu H, Wang D, Yan HH, Poon VK, Wen L, Wong BH, Zhao X, et al. (2017) Human intestinal tract serves as an alternative infection route for Middle East respiratory syndrome coronavirus. Sci Adv 3:eaao4966.

Zhou P, Yang XL, Wang XG, Hu B, Zhang L, Zhang W, Si HR, Zhu Y, Li B, Huang CL, et al. (2020b) A pneumonia outbreak associated with a new coronavirus of probable bat origin. Nature 579:270-273.

Zhou S, Wang Y, Zhu T, and Xia L (2020c) CT features of coronavirus disease 2019 (COVID-19) pneumonia in 62 patients in Wuhan, China. AJR Am J Roentgenol 214:1287-1294.

Zhou Y, Vedantham P, Lu K, Agudelo J, Carrion R Jr, Nunneley JW, Barnard D, Pöhlmann S, McKerrow JH, Renslo AR, et al. (2015) Protease inhibitors targeting coronavirus and filovirus entry. Antiviral Res 116:76-84.

Zimmerman D and Burns KD (2012) Angiotensin-(1-7) in kidney disease: a review of the controversies. Clin Sci (Lond) 123:333-346.

Zisman LS, Keller RS, Weaver B, Lin Q, Speth R, Bristow MR, and Canver CC (2003) Increased angiotensin-(1-7)-forming activity in failing human heart ventricles: evidence for upregulation of the angiotensin-converting enzyme Homologue ACE2. Circulation 108:1707-1712.

Zores F and Rebeaud ME (2020) COVID and the renin-angiotensin system: are hypertension or its treatments deleterious? Front Cardiovasc Med 7:71.

Zou L, Ruan F, Huang M, Liang L, Huang H, Hong Z, Yu J, Kang M, Song Y, Xia J, et al. (2020) SARS-CoV-2 viral load in upper respiratory specimens of infected patients. $N$ Engl J Med 382:1177-1179.

Zucker IH, Xiao L, and Haack KK (2014) The central renin-angiotensin system and sympathetic nerve activity in chronic heart failure. Clin Sci (Lond) 126: 695-706.

Address correspondence to: Ali Eid, Department of Pharmacology and Toxicology, Faculty of Medicine and Medical Centre, The American University of Beirut, P.O.BOX 11-0236, Riad El-Solh 1107 2020, Beirut, Lebanon. E-mail: ae81@aub.edu.lb; or Ahmed F. El-Yazbi, Department of Pharmacology and Toxicology, Faculty of Medicine and Medical Centre, The American University of Beirut, P.O.BOX 11-0236, Riad El-Solh 1107 2020, Beirut, Lebanon. E-mail: ae88@aub.edu.lb 